\title{
Teste de evidência como atividade investigativa sobre "transgenia e técnica de recombinante" para alunos do ensino médio.
}

\author{
Evidence Test as Investigative Activity About "Transgenic and DNA \\ Recombinant DNA Technique" for High School Students.
}

Fabrício Thiago Moura Oliveira ${ }^{1}$, Heslley Machado Silva ${ }^{2}$

${ }^{1}$ Mestre em Educação e Docência (PROMESTRE-FAE/UFMG). Especialista em Ensino de Ciências por Investigação (UFMG). Especialista em Educação na Cultura Digital (UFOP), Minas Gerais (MG), Brasil. ${ }^{2}$ Centro Universitário de Formiga (Unifor), Minas Gerais (MG), Brasil.

\section{Resumo}

Introdução: O Ensino de Ciências por Investigação tem se tornado, em conjunto com a proposta Ciência, Tecnologia e Sociedade, uma estratégia de ensino do professor para a construção do conhecimento científico do educando, possibilitando a formação de cidadãos com a capacidade de tomada de decisões. Diante dos aspectos étnicos, sociais e tecnológicos relativos aos avanços da biotecnologia, a inserção de atividades investigativas sobre a temática se faz essencial para a formação dos sujeitos. Objetivo: Mapear por meio de Testes de Evidências a estrutura cognitiva de alunos do Ensino Médio sobre transgenia e técnica de DNA recombinante e construir conhecimentos científicos que permitam a formação de educandos aptos a criticar e a debater seus pontos de vista. Metodologia: Trata-se de um relato de experiência, de abordagem qualitativa e quantitativa fundamentado na descrição e análise das atividades desenvolvidas com os alunos matriculados no $1^{\circ}$ ano do Ensino Médio de uma escola pública do estado de Minas Gerais. Resultados: A análise dos dados sugere que os educandos possuem conhecimentos incipientes sobre transgênicos. Observou-se a generalização de conceitos e processos biológicos, muitas vezes, em desacordo com os aceitos no meio científico. Apenas $25,0 \%$ dos alunos compreendem o processo biotecnológico de produção dos organismos transgênicos. Do total de educandos que reconhecem organismos oriundos da engenharia genética, 59,0\% não compreendem a diferença entre melhoramento genético e transgenia. Todavia, 65,0\% dos alunos participantes conhecem possíveis benefícios ou impactos dos transgênicos. Conclusão: A intervenção pedagógica aliada à Sequência Didática Interativa (SDI), na qual os alunos eram postos a discutir em grupos viabilizou a construção de conceitos, capacitando-os a criticar informações e reafirmar o valor da atividade investigativa para detecção e construção de conhecimentos científicos.

Palavras-chave: Desenvolvimento cognitivo; Educação científica; Estratégia da aprendizagem; Genética; Investigação em educação. 


\section{Abstract}

Introduction: The Science Education by Research has become, together with the proposed Science, Technology and Society (STS), a teaching strategy the teacher to build the scientific knowledge of the student, allowing the formation of citizens with making capacity decisions. In view of the ethnic, social and technological aspects related to the advances of biotechnology, the insertion of investigative activities on the subject is essential for the training of subjects. Objective: To map, through Evidence Testing, the cognitive structure of high school students about transgenics and recombinant DNA technique and build scientific knowledge to the formation of students are able to criticize and discuss their views. Methodology: This is an experience report, with a qualitative and quantitative approach based on the description and analysis of the activities developed with the students enrolled in the 1st year of high school in a public school in the state of Minas Gerais. Results: The analysis suggests that students have incipient knowledge about GMOs. We observe the generalization of biological concepts and processes, often in disagreement with those accepted in scientific circles. Only $25.0 \%$ of the students understand the biotechnological process of producing transgenic organisms. Of the total number of learners who recognize organisms from genetic engineering 59.0\%, do not understand the difference between genetic improvement and transgenic. However, $65.0 \%$ of the participating students are aware of possible benefits or impacts of transgenics. Conclusion: The pedagogical intervention, together with the Interactive Didactic Sequence (SDI), where the students were put to discuss in groups made possible the construction of concepts, enabling them to criticize information and reaffirm the value of research activity to detect and construct scientific knowledge.

Keywords: Cognitive development; Science education; Learning strategy; Genetics; Educational research.

\section{Introdução}

As atividades de caráter investigativo podem se caracterizar como práticas experimentais, de campo e de laboratório, demonstrações, exploração de filme, testes de evidências, elaboração de pesquisa, dentre outras ${ }^{1}$. A importância dessa metodologia no cenário de ensino de ciência tem ganhado força junto ao movimento CTS Ciência, Tecnologia e Sociedade que, em conjunto, possibilitam ao educando observar, planejar, levantar hipóteses, realizar medidas, interpretar dados, refletir e construir explicações de caráter teórico de forma a adquirir condições de entender o seu entorno, refletir, ler e entender o funcionamento básico a respeito da ciência/tecnologia ${ }^{2}$.

O aluno traz para a sala de aula ideias espontâneas adquiridas durante sua vivência social, cultural, construções pessoais e não pode ser visto como um recipiente vazio $^{3}$. Inspirada nas ideias de Piaget, a autora determina que os conhecimentos prévios dos educandos sirvam como ponto de partida para a construção de conceitos científicos.

Com a finalidade de explorar quais conhecimentos prévios, concepções espontâneas e intuitivas os alunos levam para a sala de aula, o professor de Ciências pode utilizar os Testes de Evidências, que são métodos utilizados por pesquisadores, a fim de mapear a estrutura cognitiva dos alunos. Vários instrumentos dessa natureza têm sido referidos na literatura como, por exemplo, testes de associação de palavras, entrevista clínica, técnicas de escalonamento multidimensional, análise de agrupamentos hierárquicos e testes do tipo múltipla escolha ${ }^{4}$.

Dessa forma, ao se observar as dificuldades encontradas principalmente no ensino da Genética e Biologia Molecular, é possível discutir como os Testes de Evidências com caráter investigativo podem ser aplicados em sala de aula. Essas dificuldades de compreensão podem estar relacionadas à grande complexidade no entendimento de estruturas que não são visíveis ou quase imperceptíveis aos olhos dos estudantes ${ }^{5}$. Afinal, compreender como o material genético (DNA ou RNA) é manipulado pelas técnicas de engenharia genética para a produção dos Organismos Geneticamente Modificados é bastante complexo, pois exige alto grau de abstração. Além disso, os alunos não vivenciam essas técnicas no laboratório escolar, o que também pode comprometer os processos de ensino e aprendizagem ${ }^{6}$.

Para superar esses paradigmas, é necessário que o docente utilize metodologias de ensino que contribuam para a aprendizagem dos estudantes, pois discutir sobre esses temas em sala de aula é de fundamental importância para o desenvolvimento da criticidade e da autonomia dos cidadãos. Não se pode deixar de considerar que as técnicas de engenharia genética permitem combinações de material genético em diversos tipos de seres vivos, desencadeando mudanças profundas no comportamento ético da sociedade civil $^{7}$. 
Diante desse contexto, é que o Professor de Ciências deve estar atento para discutir e explorar, em sala de aula, as questões sociais e éticas decorrentes dos avanços da Biologia Molecular, haja vista que esse campo da Biologia tem sido alvo de destaque da mídia contemporânea que trata de fatos e acontecimentos de interesse conjuntural, sem compromisso com orientações educativas. Dessa forma, ocorre a necessidade de explorar os conceitos relevantes já existentes na estrutura cognitiva dos educandos possibilitando-os a interagir com as novas ideias e tornarem-se cidadãos com capacidade de tomada de decisões, a fim de discutir criticamente informações divulgadas em jornais, revistas e televisão ${ }^{8}$.

Assim, o presente trabalho investiga a importância dos Testes de Evidências para a construção de conceitos científicos relativos a organismos geneticamente modificados (OGM) e às técnicas utilizadas na produção de transgênicos. A proposta visa a contribuir para a compreensão do conceito piagetiano de conflito cognitivo, que defende que o conhecimento prévio dos alunos tem grande influência na aprendizagem subsequente ${ }^{9}$.

A ênfase no tema proposto se dá devido à grande divulgação de pesquisas que abordam o melhoramento genético com base em bioengenharia e transgênicos, assuntos que se tornaram presentes no dia a dia de todos os cidadãos independentemente de possuírem ou não conhecimentos científicos ${ }^{10}$. Assim, o ensino voltado ao tema apresentado possibilita ao aluno criar uma base sólida de conhecimento, a fim de discutir criticamente as informações divulgadas nos meios de comunicação ${ }^{8}$.

Diante do tema, Melo e Carmo retratam que é "incipiente o número de publicações voltadas ao ensino de Genética e Biologia Molecular na escola básica brasileira"11. Logo, o presente trabalho integra-se às publicações voltadas ao ensino de genética. Para tal, objetiva-se mapear, por meio de Testes de Evidências, a estrutura cognitiva dos alunos e oportunizar a construção de conhecimentos científicos sobre transgenia e técnica de DNA recombinante, que permitam a formação de educandos aptos a criticar e a debater seus pontos de vista, melhorando suas relações com o conhecimento, consigo mesmo e com os outros, tornando-o crítico, criativo e autônomo ${ }^{12}$.

\section{Metodologia}

Esta pesquisa de abordagem mista (qualitativa e quantitativa) teve como principal foco verificar, por meio do Teste de Evidências, os conhecimentos prévios que os educandos possuem a respeito de transgenia e a técnica de DNA recombinante e utilizá-los na construção de conhecimentos científicos. Para tanto, utilizou-se como instrumento de análise o relato de experiência fundamentado na descrição das atividades desenvolvidas durante o projeto, inclusive junto aos alunos ${ }^{13}$.

As abordagens quantitativas e qualitativas se complementaram possibilitando, respectivamente, a metodologia hipotético-dedutiva para a explicação de fenômenos em análise (Teste de Evidência) e a lógica indutiva no processo de investigação. Os dados foram coletados pela observação direta das atividades, sem a preocupação de referenciá-los a objetivos predeterminados e/ou explicitados ${ }^{14}$.

O trabalho foi realizado, com os alunos matriculados no $1^{\circ}$ ano do Ensino Médio de uma escola pública do estado de Minas Gerais. A intervenção pedagógica foi ministrada por um graduando em Ciências Biológicas que realizava estágio na instituição para obtenção da titulação em licenciatura plena, em aulas teóricas de 50 (cinquenta) minutos destinadas ao conteúdo de Biologia, com auxílio de recursos multimídia, textos de divulgação científica ${ }^{5}$ e atividades elaboradas previamente. A atuação do estagiário na intervenção pedagógica foi acompanhada e registrada por meio de gravador de áudio e diário de bordo a fim de facilitar a análise dos diálogos.

A coleta de dados foi realizada em etapas distintas. No QUADRO 1, a seguir, expõe-se de forma sucinta o que foi realizado em cada etapa da intervenção didático-pedagógica realizada na escola, bem como seus objetivos. 


\begin{tabular}{|c|c|c|}
\hline MOMENTO & $\begin{array}{l}\text { PROPÓSITOS } \\
\text { PEDAGÓGICOS }\end{array}$ & OBJETIVOS \\
\hline 1 & $\begin{array}{l}\text { Aplicação do Teste de } \\
\text { Evidência (pré-teste). }\end{array}$ & $\begin{array}{l}\text { Conhecer os conceitos adquiridos durante a vivência social, cultural e } \\
\text { construções pessoais dos alunos a respeito de conceitos de genética e } \\
\text { biotecnologia com ênfase em transgenia e DNA recombinante. }\end{array}$ \\
\hline 2 & $\begin{array}{l}\text { Utilização de imagens e } \\
\text { recursos multimídia }\end{array}$ & $\begin{array}{l}\text { Expor a importância do tema, com referência às novas tecnologias } \\
\text { utilizadas e às implicações sociais e éticas dos organismos geneticamente } \\
\text { modificados. }\end{array}$ \\
\hline 3 & Intervenção pedagógica & $\begin{array}{l}\text { Construção dos conhecimentos científicos sobre transgênicos e técnica de } \\
\text { DNA recombinante. }\end{array}$ \\
\hline 4 & $\begin{array}{l}\text { Aplicação da Sequência } \\
\text { didática Interativa (SDI). }\end{array}$ & Avaliação do desempenho dos educandos após a intervenção pedagógica. \\
\hline 5 & $\begin{array}{l}\text { Debate e repasse de } \\
\text { dados. }\end{array}$ & $\begin{array}{l}\text { Avaliar com os próprios educandos se a metodologia de ensino baseada } \\
\text { nos Testes de Evidências foi eficiente. }\end{array}$ \\
\hline
\end{tabular}

QUADRO 1: As etapas da intervenção didático-pedagógica na escola. Fonte: elaborado pelo autor.

Primeiro Momento: Aplicação do Teste de Evidência (pré-teste), a fim de conhecer os conceitos adquiridos durante a vivência social, cultural e construções pessoais dos alunos a respeito de conceitos de genética e biotecnologia com ênfase em transgenia e DNA recombinante.

O Teste de Evidência foi constituído de quatro perguntas: a) Questões 1 e 2: abrangendo conceitos básicos da construção de um organismo transgênico e sua diferença com um organismo melhorado geneticamente ${ }^{5}$; b) Questão 3: os possíveis benefícios e impactos do desenvolvimento de transgênicos ${ }^{15}$ e c) Questão 4: sobre a tomada de decisão no consumo de um alimento transgênico ${ }^{16}$.

Segundo Momento: Utilização de imagens e recursos multimídia sobre a importância do tema, com referência às novas tecnologias utilizadas e às implicações sociais e éticas dos organismos geneticamente modificados.

Terceiro Momento: Aulas ministradas pelo graduando em Ciências Biológicas que realizou estágio na instituição durante o projeto, utilizando as informações coletadas no pré-teste como base para a construção do conhecimento dos estudantes.

Quarto Momento: A proposta didáticometodológica utilizada para avaliação do desempenho dos educandos após a intervenção pedagógica emprega a ferramenta de Sequência Didática Interativa (SDI) ${ }^{17}$. Essa ferramenta didática "se aplica no processo ensinoaprendizagem para sistematização de conteúdos e/ou construção de novos conhecimentos", encaixando-se na proposta do projeto a ser realizado, adaptado às necessidades de cada aluno e grupos inseridos no contexto de trabalho ${ }^{18}$.

Ainda segundo o autor:

Esta técnica pode ser usada no início de uma atividade para levantar os conhecimentos prévios dos alunos ou para o fechamento de um assunto onde o professor poderá identificar se aquele conteúdo foi bem compreendido ou não pela turma. Esta técnica é bastante dinâmica e facilita entender a fala e depoimentos dos atores sociais em seu contexto, pois se realiza em constante interação direcionando a uma visão sistêmica da temática em estudo ${ }^{18}$.

A aplicação da SDI transcreve as etapas realizadas por Gomes et al. (2013) ${ }^{18}$ adaptado ao tema de pesquisa a ser investigado e com modificações que permitiram a inserção da metodologia no presente trabalho:

I. Entregar para cada aluno do grupo-classe a "Ficha 1 - Individual" confeccionada em papel A4;

II. Solicitar que cada estudante escreva na ficha o que entende do tema trabalhado em aula. No caso da proposta didática a ser realizada, são listadas questões para a SDI com as mesmas intenções contempladas no Teste de Evidência (pré-teste) aplicado anteriormente:

a) O que são OGMs? São todos obtidos por Melhoramento Genético ${ }^{19}$

b) Cite, resumidamente, os passos para a obtenção de um organismo transgênico ${ }^{19}$.

c) Quais os possíveis benefícios e impactos dos transgênicos? ${ }^{15}$

d) Você acredita que o consumo de OGMs é prejudicial à saúde humana?

III. Depois que cada estudante escrever o que entende do tema em estudo (conceito), dividir a classe em pequenos grupos. Uma vez formados esses grupos, solicitar aos estudantes que respondam a "Ficha 2 Grupo" com os conceitos que foram construídos por cada participante, resumindo em uma só resposta o que o grupo considera correto (definição). É importante que o grupo tente contemplar, nas respostas, o que cada participante disse sobre o tema.

IV. Na etapa seguinte, é solicitado que cada equipe escolha um representante. Assim, é formado um novo grupo somente com o líder de cada equipe da etapa anterior. $\mathrm{O}$ professor solicita que os líderes respondam a "Ficha 3 - Final", com base nas respostas dadas por 
todos os grupos, ou seja, é elaborada uma síntese para responder a SDI, contemplando as respostas anteriores "Ficha 1 - Individual" e "Ficha 2 - Grupo" de modo consensual, resultando na construção de respostas para as questões que consideram corretas.

Quinto Momento: Debate e repasse de dados coletados dos alunos, a fim de discutir com os próprios educandos se a metodologia de ensino baseada nos Testes de Evidências investigativo foi eficiente, demonstrando por meio de gráficos quantitativos os resultados obtidos.

Os dados coletados foram transformados em gráficos, buscando facilitar a análise. Foi realizado um estudo comparativo entre os conhecimentos prévios e os adquiridos após as atividades, além de se observar e registrar, durante todo o processo, questionamentos, dificuldades e dilemas a fim de enriquecer o trabalho ${ }^{20}$.

\section{Resultados}

Os resultados obtidos por meio do Teste de Evidências foi um importante instrumento para avaliar quais os conhecimentos prévios adquiridos da vivência social, cultural e construções pessoais os estudantes possuem acerca de conceitos relevantes sobre Genética e Biotecnologia com ênfase em Transgenia e DNA Recombinante ${ }^{4}$.

O teste foi aplicado em uma amostra de quarenta alunos das turmas do primeiro ano do Ensino Médio, que se dispuseram a participar da pesquisa e forneceram o Termo de Consentimento Livre e Esclarecido preenchido pelos pais ou responsáveis, autorizando a participação dos alunos nas atividades. Os alunos participantes correspondem a $20 \%$ (vinte por cento) do total de alunos cursando o primeiro ano do Ensino Médio na escola.

Os resultados mostraram que $72,50 \%$ dos alunos apresentam conhecimentos prévios que os permite diferenciar corretamente as figuras sobre o melhoramento genético ou transgênico (FIGURA 1).

Figura 1

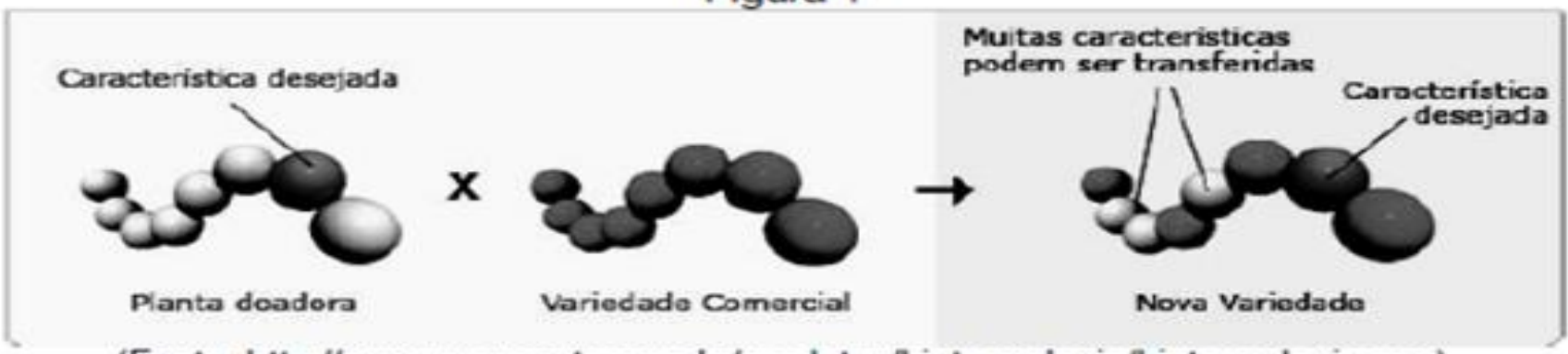

(Fonte: http///www.monsanto.com.br/produtos/biotecnologia/biotecnologia.asp)

\section{Figura 2}

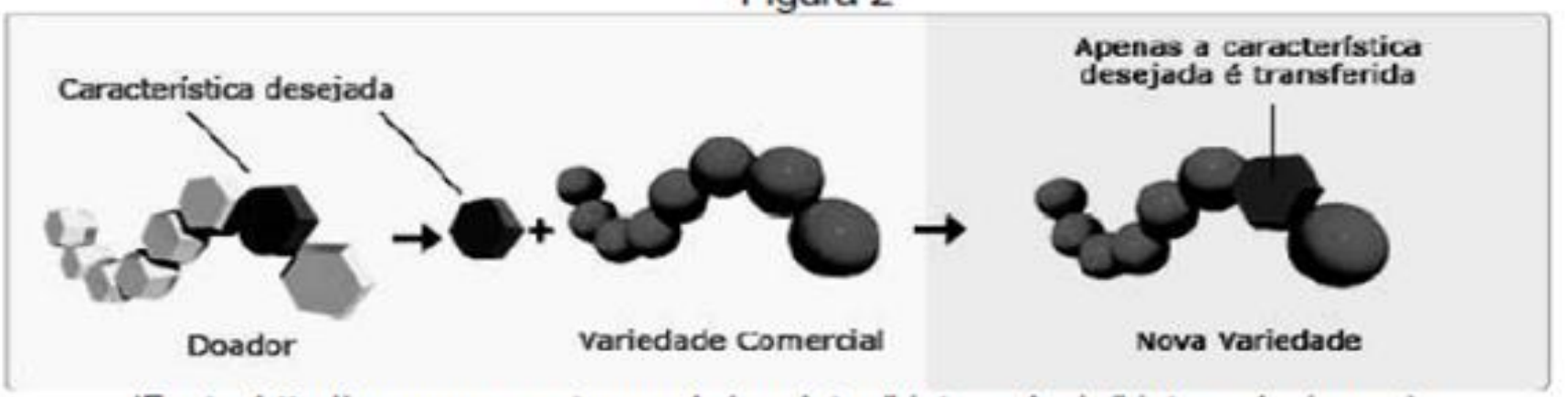

(Fonte: http///www.monsanto.com.br/produtos/biotecnologia/biotecnologia.asp)

FIGURA 1: Figuras 1 e 2 da questão 1 do Teste de Evidências.

Todavia, dos $72,50 \%$ dos educandos que responderam corretamente à Questão 1a, a maioria $59,00 \%$ - não conseguiu justificar corretamente a resposta na Questão 1b. Observou-se que os participantes também apresentaram dificuldades em descrever o processo pelo qual um organismo transgênico é produzido.

O questionamento frente aos possíveis benefícios e impactos provenientes do desenvolvimento dos transgênicos, também, revelaram a presença de concepções prévias na estrutura cognitiva dos estudantes.
Os dados coletados mostraram que $65,00 \%$ dos alunos conhecem (Sim), os possíveis benefícios ou impactos oriundos dos transgênicos e que 31,00\% não conhecem (Não) ou não souberam responder quais os benefícios ou impactos oriundos dos transgênicos. Alinhado às concepções dos estudantes sobre os benefícios e impactos dos transgênicos, a maioria revelou positivamente sobre a decisão de consumir alimentos transgênicos.

Uma vez que os alunos demonstraram carência de conhecimentos para descrever as diferenças entre 
melhoramento e transgenia, a intervenção pedagógica oportunizou a problematização desses conceitos científicos. As dificuldades expostas pelos alunos no Teste de Evidências serviram de base para planejar a intervenção pedagógica e posteriormente viabilizar a discussão entre alunos na Sequência Didática Interativa.

A ferramenta de Sequência Didática Interativa (SDI) possibilitou a sistematização de conteúdos e a identificação de conhecimentos científicos adquiridos na intervenção pedagógica por meio de depoimentos construídos pela interação aluno-aluno e proporcionada pelo dinamismo resultante da $\mathrm{SDI}^{18}$.

O primeiro momento da atividade contou com a explicação sobre o processo metodológico proposto pela Sequência Didática Interativa. Isso foi bem aceito pelos alunos ao perceberem que, em certo momento da atividade, formariam grupos, para debaterem suas respostas e chegarem a um consenso sobre qual seria a resposta da equipe (Ficha 2 - Grupo).

Como proposto pela metodologia, após a conclusão da "Ficha 2 - Grupo", os integrantes de cada equipe escolheram um representante (líder) para a participação na última etapa do SDI. Na terceira etapa, os alunos escolhidos como representantes das equipes iniciais formaram um novo grupo para responder a "Ficha 3 - Final", permitindo a reconstrução das respostas da etapa anterior (Ficha 2 - Grupo). Esse momento da SDI propiciou a elaboração de uma resposta final feita após discussão e consenso dos líderes, de modo a elaborar resoluções que refletissem a opinião geral em relação aos questionamentos previstos para a SDI.
A participação dos representantes, nessa etapa, também foi bastante dinâmica e cada representante relatou e defendeu a opinião de sua equipe. Ao final da SDI, foram obtidas duas unidades da "Ficha 3 - Final", correspondentes ao Grupo A e ao Grupo B, que realizaram a metodologia separadamente.

\section{Discussão}

Os resultados coletados pelo Teste de Evidência, Intervenção pedagógica e Sequência Didática Interativa (SDI) permitiram identificar os conhecimentos prévios dos educandos e construir coletivamente conhecimentos relativos à transgenia e técnica de DNA recombinante. A análise e discussão dos resultados nas diferentes etapas são expostos por meio de narrativas e dados quantitativos que demonstram o alcance do Teste de Evidências para mapear a estrutura cognitiva dos alunos e a contribuição da SDI para formação de educandos aptos a criticar e a debater seus pontos de vista.

Os resultados do Teste de Evidências (pré-teste) são confrontados com trabalhos semelhantes ${ }^{5 ; 15}$ que buscaram conhecer concepções dos alunos referentes as transgenia e melhoramento genético. Assim, além dos resultados quantitativos, consideramos o contexto escolar e social dos educandos participantes da pesquisa.

A Questão 1a introduz, brevemente, a história e as características da manipulação genética, propondo ao aluno "a conceituação sobre a construção de um organismo transgênico e sua diferença com um organismo melhorado geneticamente" "5 (GRÁFICO 1).

\section{QUESTÃO 1a - Indique qual a figura que representa a nova variedade gerada por melhoramento e qual foi gerada por transgenia.}

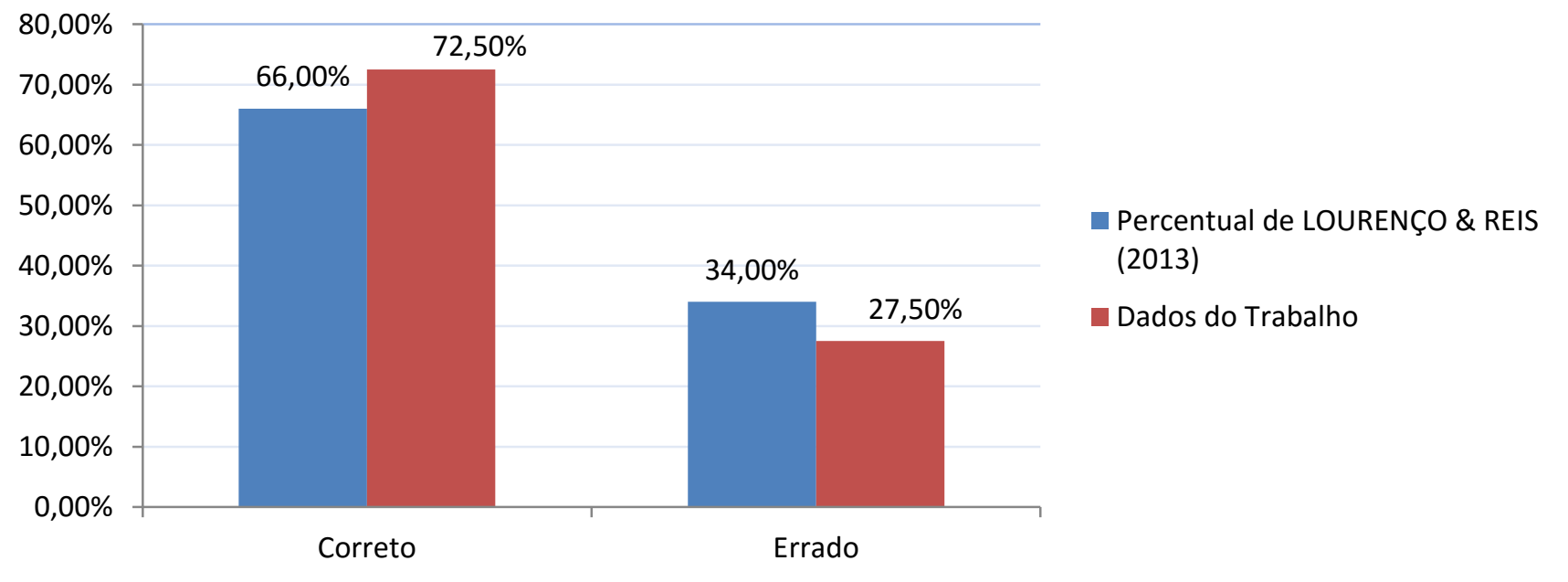

GRÁFICO 1: Comparação das respostas dadas pelos alunos na Questão 1a. Correto: Conseguiram identificar corretamente as figuras. Errado: Não conseguiram identificar corretamente as figuras. Fonte: LOURENÇO E REIS (2013) e dados da pesquisa.

Dos $72,50 \%$ dos educandos que responderam corretamente à Questão 1a, a maioria - 59,00\% - não conseguiu justificar corretamente a resposta na Questão 1 b (TABELA 1), mostrando a "não compreensão entre os processos de melhoramento genético e transgenia", fato também observado ${ }^{5}$.

O incipiente embasamento científico pôde ser observado nas respostas dos alunos "A e B": 
Aluno A - "Na figura 1, pode-se ver que ainda restam características indesejadas, mostrando que só houve melhoramento. Na figura 2, podese ver que só há característica desejada, mostrando que houve uma mutação para que ficasse com uma perfeição”.
Aluno B - "Porque na transgenia apenas a característica desejada é transmitida, o outro é modificado em laboratório, mas sem receber material genético".

TABELA 1 - Dados obtidos na Questão 1b de Lourenço e Reis (2013) versus dados obtidos no trabalho.

\section{TABELA COM OS PERCENTUAIS OBSERVADOS}

\begin{tabular}{ccc}
\hline & $\begin{array}{c}\text { LOURENÇO \& } \\
\text { REIS (2013) }\end{array}$ & Dados da Pesquisa \\
\hline Correto & $33,00 \%$ & $41,00 \%$ \\
\hline Errado & $67,00 \%$ & $59,00 \%$ \\
\hline Total & $\mathbf{1 0 0 , 0 0 \%}$ & $\mathbf{1 0 0 , 0 0 \%}$ \\
\hline
\end{tabular}

Fonte: Lourenço e Reis (2013) e dados da pesquisa.

As Questões 1a e 1b possibilitaram identificar que a maior parte dos integrantes da amostra traz para a sala de aula conhecimentos prévios acerca da construção de organismo melhorado e produzido por transgenia. Porém, ao justificar a resposta (Questão 1b), observa-se a generalização dos conhecimentos prévios dos alunos, que estão em desacordo com os aceitos no meio científico ${ }^{4}$.

Essas evidências são importantes para o professor orientar as próximas atividades a serem desenvolvidas e complementar as lacunas do conhecimento científico dos educandos. Nesse enfoque, o desempenho dos estudantes na questão $1 \mathrm{a}$ e $1 \mathrm{~b}$, pode ser considerado facilitador para a aprendizagem subsequente ${ }^{9}$.

A Questão 2 propunha que os alunos se expressassem sobre como um transgênico é produzido a partir da figura que lhes foi fornecida. Em seu trabalho observaram que poucos alunos responderam corretamente, fato justificado pela complexidade e conjunto de conceitos que envolvem o processo da produção de uma planta transgênica ${ }^{5}$.

A utilização dessa questão no presente trabalho possibilitou verificar que apenas $25,00 \%$ possuem algum conhecimento de como uma planta transgênica é produzida, observando em alguns casos a apropriação de termos científicos presentes na imagem. Como exemplo, temos a resposta do "Aluno C":

Aluno C - "Eles isolam o DNA da bactéria e fazem a extração do gene de interesse para fabricar o gene, formando assim uma planta transgênica”.

Algumas respostas demonstraram que o aluno não conseguiu identificar o esquema apresentado como os passos para a produção de uma planta transgênica, ocorrendo confusão com outros conceitos da biologia:

Aluno X: "O vírus que faz mal à planta é recolhido e seu DNA é retirado para fazer melhorias na planta, para ela ficar imune a esse vírus",

Aluno Y: “A planta não é capaz de reproduzir aí ocorre a utilização do DNA de uma certa bactéria que melhora a reprodução”.

Com relação à Questão 2, o GRÁFICO 2 representa a comparação com os resultados obtidos 5 . 


\section{QUESTÃO 2 - De acordo com seus conhecimentos sobre transgênicos explique o que representa a figura (Apêndice).}

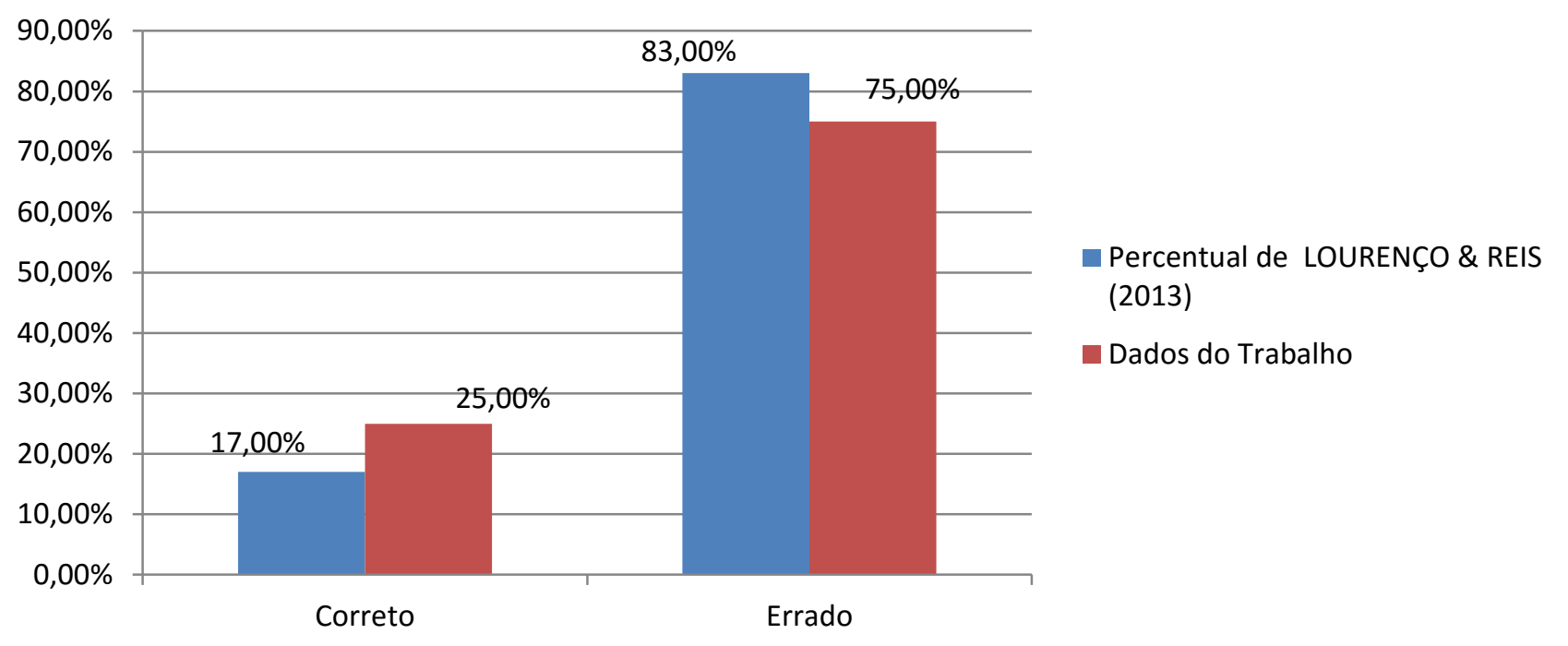

GRÁFICO 2: Comparação da compreensão dos alunos sobre processo no qual o transgênico é construído. Correto: Responderam corretamente a questão. Errado: Responderam incorretamente a questão. Fonte: LOURENÇO E REIS (2013) e dados da pesquisa.

Os estudantes foram questionados na Questão 3 sobre os possíveis benefícios e impactos provenientes do desenvolvimento dos transgênicos. Os dados coletados mostraram que parcela significativa dos alunos conhecem (Sim) os possíveis benefícios ou impactos oriundos dos transgênicos e que são poucos os educandos que não conhecem (Não) ou não souberam responder quais os benefícios ou impactos oriundos dos transgênicos.
O mesmo questionamento, sobre os possíveis benefícios e impactos dos transgênicos, foi feito a alunos da graduação nas áreas Biomédica, Social, Humanas e Tecnológica da Universidade do Estado do Rio de Janeiro $^{15}$. Os resultados obtidos foram distintos (GRÁFICO 3).

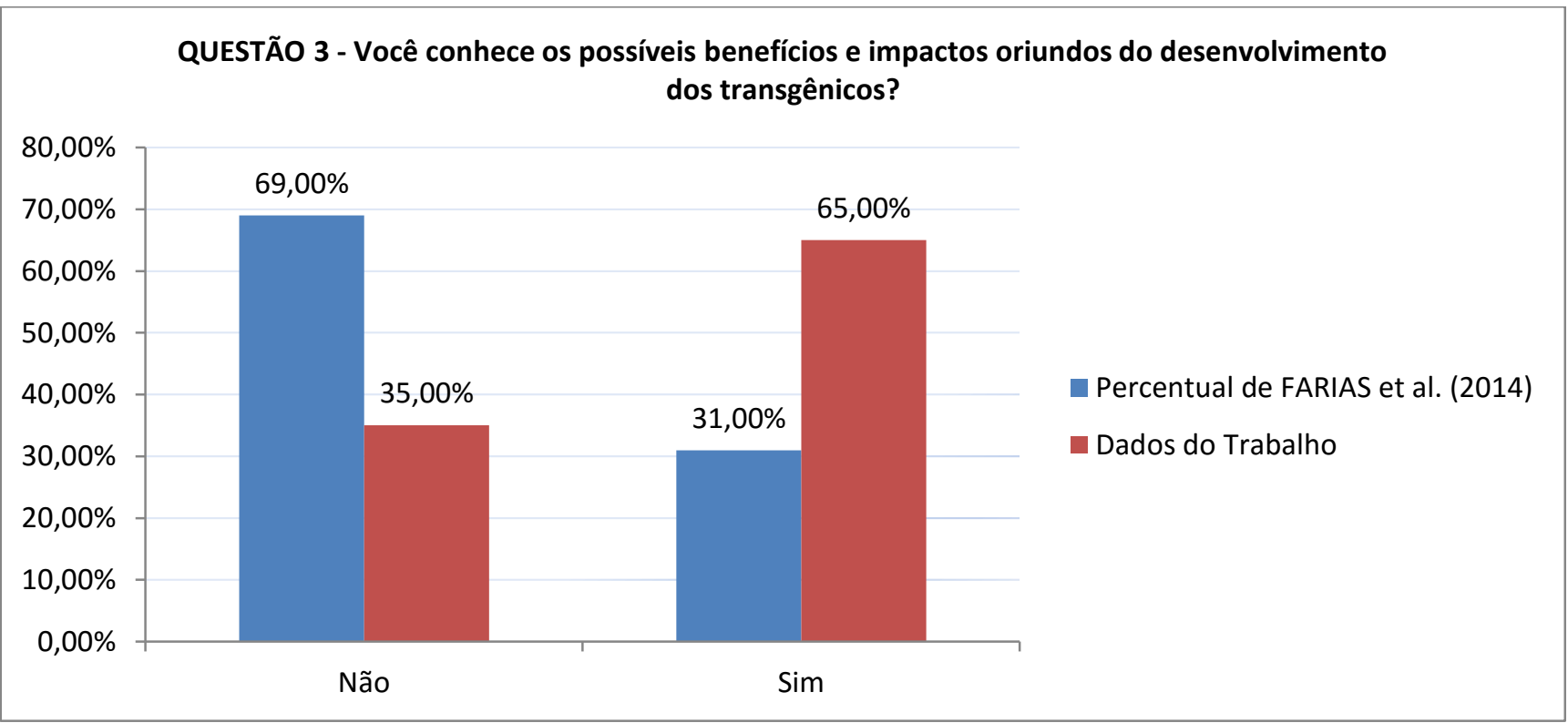

GRÁFICO 3: Comparação da compreensão dos alunos sobre possiveis benefícios ou impactos oriundos dos transgênicos. Não: Não conhecem benefícios ou impactos. Sim: Conhecem benefícios ou impacto. Fonte: FARIAS et al. (2014) e dados da pesquisa.

Considerando que o público alvo da pesquisa realizada $^{15}$ era representado por alunos da graduação, esperava-se um maior conhecimento dos graduandos acerca dos possíveis benefícios ou impactos oriundos dos transgênicos. 
O autor revela o mesmo posicionamento acerca da percepção incipiente dos granduandos sobre a temática:

\begin{abstract}
Em uma pesquisa onde o público alvo restringiu-se aos alunos de graduação de uma universidade pública, esperava-se um conhecimento mais amplo sobre a temática dos transgênicos, visto que os entrevistados estão inseridos em um grupo seleto de brasileiros, que têm acesso a discussões e informações mais refinadas sobre questões

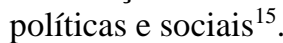

A discrepância entre os resultados ${ }^{15}$ e os obtidos pode ser conjuntamente justificada pela participação, na presente amostra, de um número significativo de alunos da disciplina Meio Ambiente que já trabalharam na relação Transgênicos/Ambiente, e pela atuação da Empresa Brasileira de Pesquisa Agropecuária (Embrapa Milho e Sorgo), instalada no municipio, a qual periodicamente realiza atividades abertas ao público. Esse fato foi comprovado pelo conhecimento de alguns alunos do Ensino Médio sobre o Milho Bt versus "Lagarta do Cartucho do Milho" (Spodoptera frugiperda) em que um aluno participante desta pesquisa aponta o conhecimento a respeito do "milho imune à lagartas".

A justiticativa dos alunos confirma a hipótese de a Embrapa ter influência nos resultados obtidos, pois grande parte dos educandos citaram benefícios ligados à produção agrícola: Aumento/Melhora na Produção, Resistência a Pragas e Valor Nutritivo. Outros benefícios dos trangênicos identificados foram: Conservação de espécies, Novas Variedades/Manipulação Genética e Saúde. Alguns beneficios observados na Questão 3 e sua respectiva ideia central estão em destaque no QUADRO 2.

\begin{tabular}{|c|c|}
\hline Benefícios identificados & Ideias centrais \\
\hline $\begin{array}{c}\text { “... acabando com a dengue...”, “... Vai beneficiar a área da } \\
\text { saúde..” e “... novos remédios.. ” }\end{array}$ & Saúde \\
\hline $\begin{array}{l}\text { “... a planta irá adquirir imunização contra bactérias.. ”, “... milho } \\
\text { imune a lagartas.. ”, “... criação de plantas mais resistentes.. ” }\end{array}$ & Resistência a pragas \\
\hline $\begin{array}{c}\text { “... milho de pipoca que estoure mais rápido..." } e \text { “..melhorar o } \\
\text { DNA e criar novas variedades..." }\end{array}$ & Novas Variedades/Produção \\
\hline 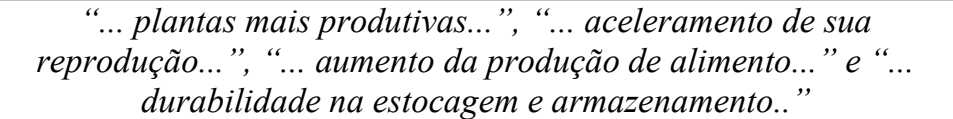 & Aumento/Melhora na produção \\
\hline “...conservação de espécies.” & Conservação de espécies \\
\hline “... pode aumentar certas proteínas...” & Valor nutritivo \\
\hline
\end{tabular}

QUADRO 2: Algumas respostas obtidas na Questão 3 com suas respectivas ideias centrais. Fonte: Dados da pesquisa.

O GRÁFICO 4 exibe a frequência de benefícios identificados entre os $65,00 \%$ dos estudantes que responderam (Sim) conhecer algum benefício ou impacto dos transgênicos. Os valores apresentados referem-se ao percentual do número de vezes que determinado benefício foi citado, ou seja, a frequência com que foi observado determinado benefício nos questionários analisados. 


\section{QUESTÃO 3 - Frequência de Benefícios identificados}

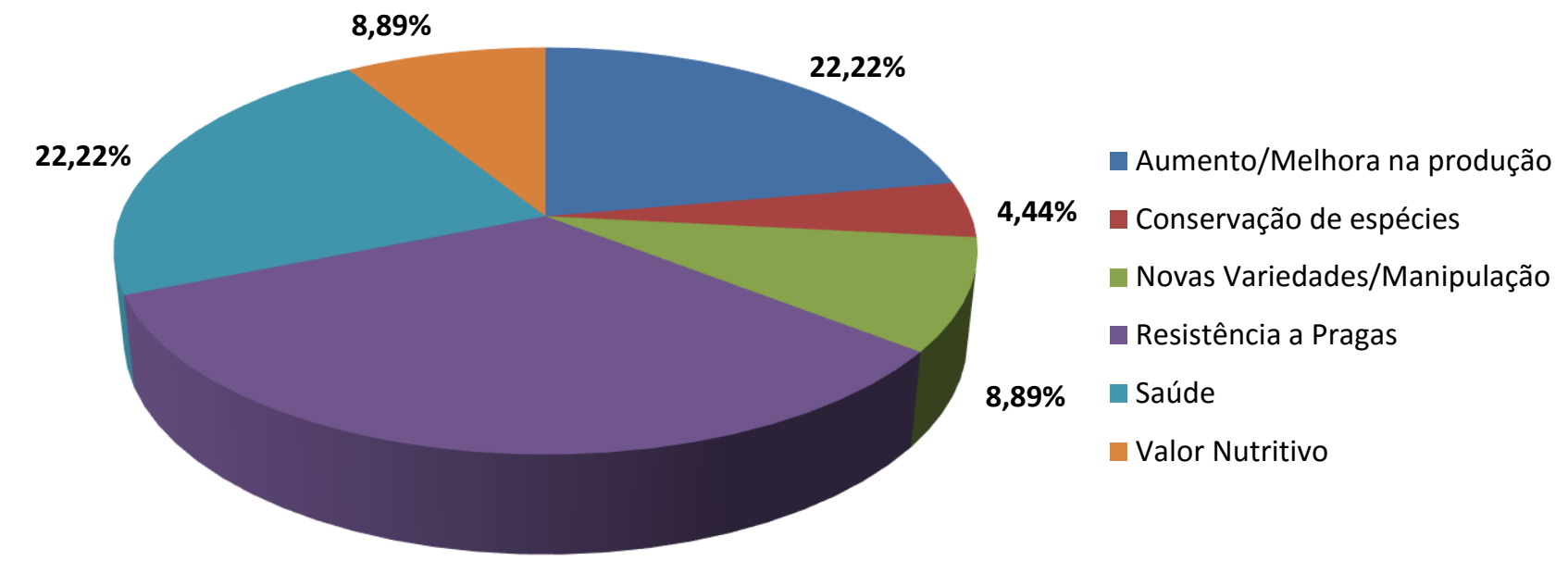

$33,33 \%$

GRÁFICO 4: Frequências de benefícios identificados na questão 3 do Teste de Evidências. Fonte: Dados da pesquisa.

Entre os estudantes que afirmaram conhecer benefícios ou impactos (Sim), 46,15\% justificaram a questão, citando como impactos dos transgênicos: Cancerígenos $(8,33 \%)$, Criar Pragas/Doenças $(33,33 \%)$, Impacto ao Meio Ambiente $(50,00 \%)$ e Produção de planta venenosa $(8,33 \%)$.

A Questão 4, retirada do trabalho ${ }^{5}$, abordou a postura dos estudantes em relação à presença de transgênicos na alimentação, especificamente na merenda escolar.

Observou-se nos resultados que a maioria dos alunos consumiriam a merenda escolar independentemente da presença de transgênicos (arroz, feijão, trigo e soja). Entre as justificativas pelo consumo, observou-se que alguns alunos relacionam os transgênicos como mais nutritivos:

\begin{abstract}
Aluno F: “... já estamos ingerindo esse tipo de alimento, pois aumentaram as proteínas dos alimentos...”.
\end{abstract}

Aluno H: “... com a transgenia pode haver alimentos mais saudáveis e com mais fontes de proteinas, vitaminas...".

Lourenço e Reis $(2013)^{5}$ relataram em sua pesquisa que, da mesma forma, alguns alunos consumiriam transgênicos devido à qualidade nutricional.

A postura dos alunos diante do consumo de merenda preparada com alimentos transgênicos é facilmente visualizada no GRÁFICO 5, que expõe as respostas dos alunos (Sim/Não) em comparação com as obtidas $^{5}$. 


\section{QUESTÃO 4 - Se um dia você descobrisse que os alimentos fornecidos para a preparação da merenda na sua escola (arroz, feijão, trigo e soja) são de origem transgênica, você consumiria a merenda?}

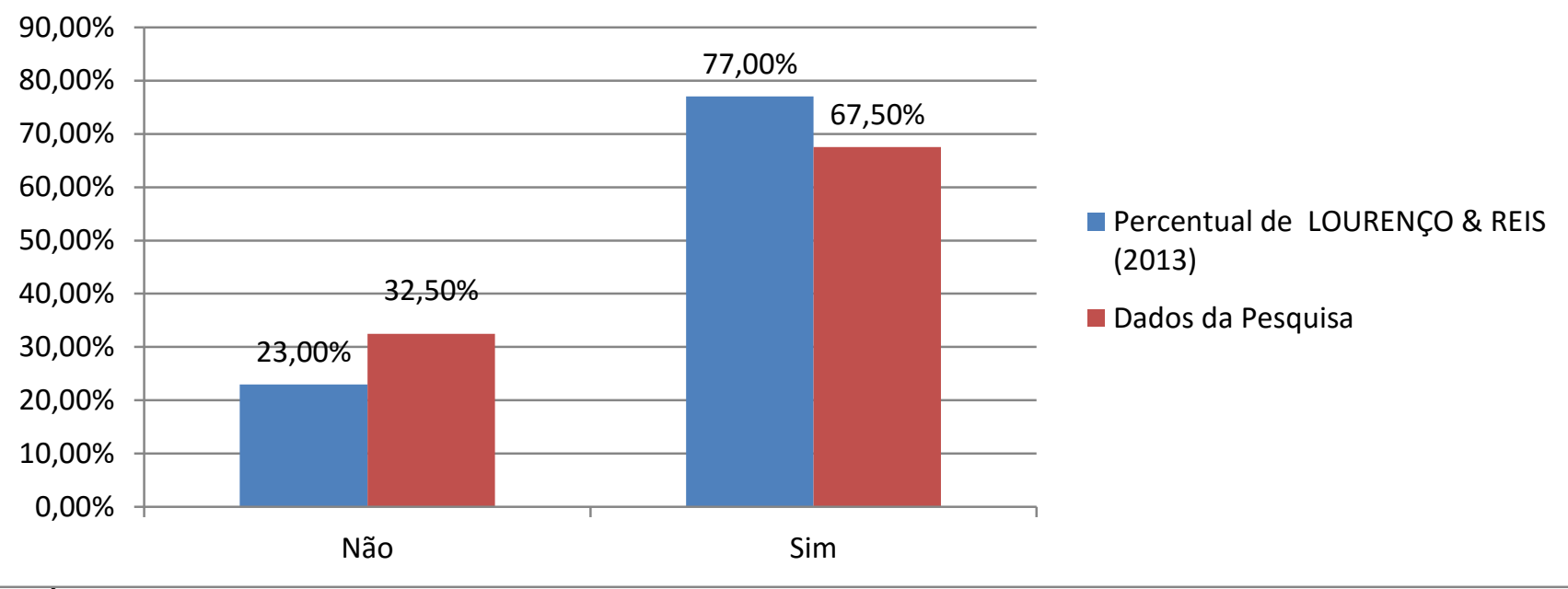

GRÁFICO 5: Postura dos alunos no consumo de merenda preparada com alimentos de origem transgênica. Não: Não consumiria/Não soube responder. Sim: Consumiria. Fonte: LOURENÇO E REIS (2013) e dados da pesquisa.

Após a aplicação do Teste de Evidência, em dia e horário pré-definidos, os alunos foram convidados a participar de uma aula com duração de 1 hora e $30 \mathrm{~min}$, planejada com base nos dados obtidos do pré-teste. Uma vez que os alunos demonstraram carência de conhecimentos para identificar a diferença entre melhoramento e transgenia, foi realizada a problematização de conceitos científicos por meio de perguntas direcionadas:

Professor (estagiário): “... os organismos geneticamente modificados (OGM) ou transgênicos são aqueles cujo genoma foi artificialmente manipulado pela introdução, modificação ou inativação de um gene...”.

Professor (estagiário): “... gente, quando eu falo em introdução de um gene, este gene pode ser proveniente de outra espécie diferente! Entenderam?".

Professor (estagiário): "Então me digam: se eu tenho uma lavoura de milho de pequeno porte e quero obter milho apenas de grande porte, $e$ para isso realizo o cruzamento do meu milho (pequeno) com o milho do meu vizinho (grande) [...] Com esta introdução já dá para saber se estou diante de melhoramento ou transgenia?".

questionamento:

Os alunos se agitaram para responder $\mathrm{o}$

Aluno H: "Sim, porque se não foi introduzido gene, então não é transgênico. Isso é natural...”.

Aluno S: “.... Não é transgênico porque só utilizou o milho.”.

Observou-se que alguns alunos consideram transgênico apenas aquele organismo que recebeu material genético de uma espécie diferente, como apontado pelo Aluno S. Nesse momento, o ministrante interveio explicando corretamente a diferença entre os dois processos e encerrou a discussão.

As aplicações da biotecnologia foram explanadas e exibidas por Slides com exemplos na área industrial, ambiental e científica, na saúde e na agricultura, mostrando à classe/grupo critérios da biotecnologia considerados benéficos para a humanidade.

Para explicar como um organismo transgênico é produzido e procurando desmistificar conceitos sobre o tema, foram exibidas animações que fazem parte da imaginação de alguns alunos que convivem com os conceitos adquiridos de suas vivências culturais e sociais, errôneas perante os conceitos científicos atualmente aceitos.

Ao observar as imagens, os alunos ficaram curiosos quanto à possibilidade de produzir plantas e animais com características "monstruosas". O ministrante justificou que não seria possível transmitir certas características e, mesmo que o fosse, a questão ética impediria certos experimentos.

Para explicar como é produzido um organismo transgênico, foi necessário relembrar aos alunos conceitos fundamentais da genética e posteriormente discursar, com ajuda de esquemas gráficos, como ocorre a técnica de DNA recombinante.

A produção agrícola foi utilizada para exemplificar a aplicação de transgênico por meio da produção do Milho bt a partir da extração do Gene bt da bactéria Bacillus thuringiensis. Ao final da aula, foi proposta aos alunos uma discussão sobre transgênicos e a problemática existente sobre o tema por meio da Sequência Didática Interativa (SDI).

A intervenção junto aos aspectos metodológicos e dialógicos da SDI permitiram reconhecer a construção 
de um entendimento sobre os conceitos científicos referentes a OGMs. Os educandos mostraram discernir entre organismo melhorado e transgênico, como observado na resposta final dada pelo Grupo B: "Organismos geneticamente modificados. Não, porque também pode ser por transgenia.”.

Com o objetivo de verificar a assimilação de conceitos científicos relacionados aos passos necessários observado nas respostas da Questão 2 (Ficha 3 - Final) de ambos os grupos/classe uma dificuldade em relatar de forma correta a sequência de eventos realizados para a obtenção de um transgênico.

Para a resolução da Questão 2 (Ficha 3 - Final), o Grupo A elaborou um esquema buscando relatar corretamente os passos para obtenção de um organismo transgênico (FIGURA 2).

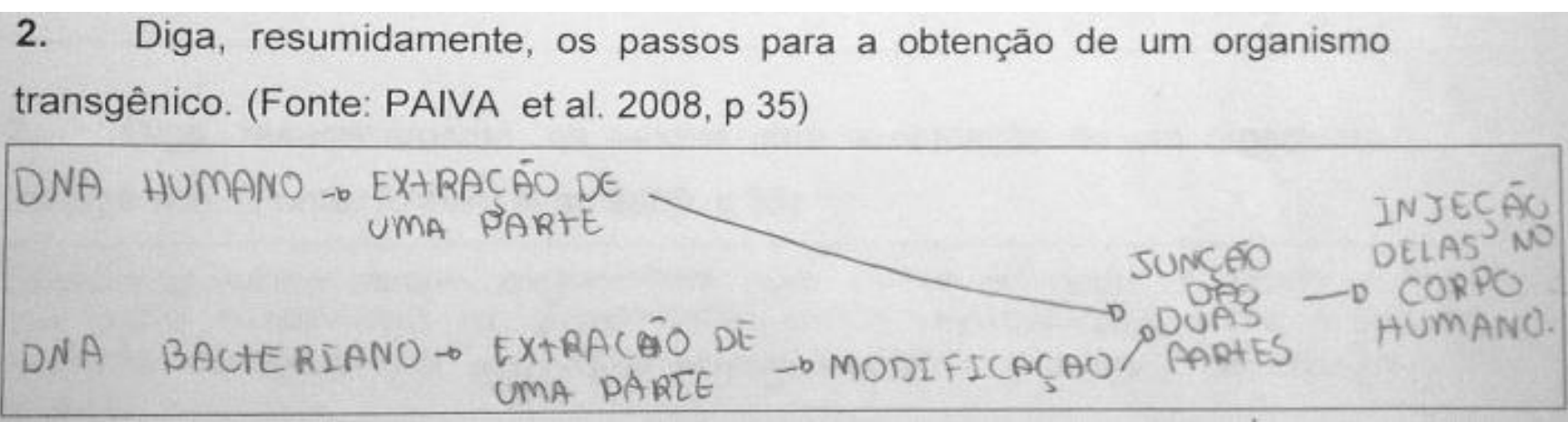

para a obtenção de organismos transgênicos, foi

FIGURA 2: Esquema produzido pelo grupo A como resposta a Questão 2 da SDI. Ficha 3 - Final. Fonte: Dados da pesquisa.

O esquema (Figura 2) representado na "Ficha 3 Final", evidencia a não compreensão do processo científico pelo qual o transgênico é construído e a dificuldade em expressar termos científicos. Tal dificuldade pressupõe que os educandos possuem uma carência de conhecimentos na área de genética, fato comprovado ao serem questionados pelo professor/pesquisador e alguns responderem que não haviam estudado genética em nenhum momento do ciclo escolar.

Abordam outro fator como responsável pela deficiência na compreensão dos passos de produção dos transgênicos e citam a "complexidade e o conjunto de conceitos que envolvem o processo da produção" como fatores que dificultam o entendimento por parte dos alunos ${ }^{5}$.

Diante dos dados obtidos na Questão 2 (Ficha 3 - Final), considera-se que a intervenção pedagógica não foi suficiente para a aquisição, por parte dos educandos, de conceitos científicos concretos sobre os passos para a obtenção de um organismo transgênico, e que no decorrer do ciclo escolar este conteúdo seja trabalhado novamente pelo professor de Biologia.

A fim de verificar a aprendizagem dos alunos após a aquisição de conceitos científicos relacionados a possíveis benefícios e impactos dos transgênicos (Questão 3 e Questão 4) observou-se, ao final da SDI, que os alunos se apropriaram de conhecimentos sobre o assunto (QUADRO 3).

\begin{tabular}{|c|c|c|}
\hline & Benefícios & Impactos \\
\hline 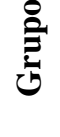 & $\begin{array}{c}\text { “Ajuda no crescimento e melhoramento, aumento } \\
\text { no rendimento, resistência a pragas e resistências } \\
\text { a variações climáticas.”. }\end{array}$ & $\begin{array}{l}\text { "Desenvolvimento desordenado, extinção involuntária de } \\
\text { espécies afetadas, afeta o alimento transgênico.". }\end{array}$ \\
\hline$\overbrace{\substack{0 \\
0}}^{\infty}$ & "Ajuda a produzir mais e gera mais economia.". & $\begin{array}{c}\text { "A planta pode rejeitar o DNA e morrer, falta de } \\
\text { pesquisas sobre seus impactos futuros e preconceito } \\
\text { sobre tais produtos." }\end{array}$ \\
\hline
\end{tabular}

QUADRO 3: Benefícios e Impactos dos transgênicos citados pelos alunos etapa final da SDI. Questão 3 (Ficha 3 - Final). Fonte: Dados da pesquisa.

As respostas dadas na "Ficha 3 - Final" pelos grupos/classes A e B em relação aos benefícios e impactos dos transgênicos (Questão 3) integram o conceito CTS Ciência, Tecnologia e Sociedade. Os educandos, após discutirem e elaborarem respostas consensuais, utilizaram conhecimentos científicos para a construção de explicações e justificativas: “... falta de pesquisas sobre seus impactos futuros...".
A construção de conceitos científicos a partir de outros já existentes na estrutura cognitiva dos alunos foi estimulada pela Sequência Didática Interativa que, ao permitir debates entre integrantes dos grupos (Ficha $2-$ Grupo) e entre líderes de grupos (Ficha 3 - Final), possibilitou a tomada de decisões, preparando o educando a discutir criticamente informações divulgadas nas mais diversas mídias. 
Há de se ressaltar, mais uma vez, que a SDI revelou a influência do conhecimento científico construído ao longo das etapas do projeto na tomada de decisões acerca do consumo de transgênicos e sua relação prejudicial com a saúde humana (QUADRO 4).

\begin{tabular}{|c|c|}
\hline \multicolumn{2}{|c|}{ QUESTÃO 4 - Você acredita que o consumo de OGMs é prejudicial à saúde humana? } \\
\hline Grupo A & Grupo B \\
\hline $\begin{array}{c}\text { Não. Pois testes são realizados para garantir a } \\
\text { qualidade do produto e até hoje não foi } \\
\text { comprovado prejuizos à saúde. }\end{array}$ & $\begin{array}{c}\text { "Não, pelo contrário. O uso de OGMs é benéfico à saúde humana, } \\
\text { mas são necessários melhores estudos sobre tais processos. }\end{array}$ \\
\hline
\end{tabular}

QUADRO 4 - Respostas finais da Sequência Didática Interativa (Questão 4) do Grupo A e Grupo B na Ficha 3 - Final. Fonte: Dados da pesquisa.

Ambos os grupos citaram na "Ficha 3 - final" não acreditar que o consumo de organismos geneticamente modificados seja prejudicial à saúde humana. Justificaram a opinião construída de forma coerente, buscando utilizar os conhecimentos científicos como embasamento para a defesa de suas respostas.

\section{Conclusão}

A análise da estrutura cognitiva dos educandos possibilitada pelo Teste de Evidência revelou que os alunos possuem concepções formadas ao longo de sua vivência social. No entanto, a maior parte da amostra não possuía um embasamento científico para se posicionar sobre o assunto. A intervenção pedagógica possibilitou aos educandos o contato com conceitos científicos sobre o tema mostrando-se válida, porém de curta duração para um adequado entendimento do processo de transgenia. Nesse sentido, considera-se que, apesar da evidente contribuição da metodologia empregada para a aprendizagem, um domínio maior sobre aspectos básicos da genética é importante para se compreender a transgenia e técnica de DNA recombinante.

Todavia, considerando os objetivos previamente estabelecidos e o contexto escolar dos sujeitos participantes da pesquisa, a metodologia de ensino empregada colaborou para a discussão sobre benefícios e impactos dos transgênicos e a tomada de decisão frente a seu consumo. $\mathrm{O}$ debate entre alunos foi enriquecedor para o estabelecimento da criticidade pautada em argumentos solidificados em conhecimentos científicos, aproximando a prática escolar das práticas tipicamente científicas.

Ademais, foi verificada a integração entre o Ensino de Ciências por Investigação e a proposta Ciência, Tecnologia e Sociedade - CTS - na formação de discentes. Aconselha-se a diversificação de práticas pedagógicas para o ensino de Ciências e Biologia e a retomada do conteúdo de genética pelo professor, em momento oportuno, redirecionando a prática pedagógica aos conceitos científicos não compreendidos pelos alunos que participaram da pesquisa.

\section{Declaração de conflitos de interesse}

Os autores do artigo afirmam que não houve nenhuma situação de conflito de interesse, tais como propostas de financiamento, emissão de pareceres, promoções ou participação em comitês consultivos ou diretivos, entre outras, que pudessem influenciar no desenvolvimento do trabalho.

\section{Referências}

1. CASTRO, M. E. C.; MARTINS, C. M. C; MUNFORD, D. Ensino de Ciências por investigação. Belo Horizonte. 2008. p. 84-89.

2. PINHEIRO, N. A. M.; SILVEIRA, R. M. C. F.; BAZZO, W. A. Ciência, Tecnologia e Sociedade: A relevância do enfoque CTS para o Contexto do Ensino Médio. Ciência \& Educação. p. 71-84. 2007.

3. JÓFILI, Z. Piaget, Vygotsky, Freire e a construção do conhecimento na escola. Educação: Teorias e Práticas. 2002. p.191-208.

4. SILVEIRA, F. L.; MOREIRA, M. A.; ATX, R. Validação de um teste para detectar se o aluno possui a concepção Newtoniana sobre força e Movimento. Ciência e Cultura. p. 2047-2055. 1986.

5. LOURENÇO, A. P.; REIS, L. G. Transgênicos na sala de aula: concepções e opiniões de alunos do Ensino Médio e uma prática pedagógica. Revista Vozes dos Vales. 2013. p. 1- 27.

6. ANDRADE, M. L. F.; MASSABNI, V. G. O desenvolvimento de atividades práticas na escola: um desafio para os professores de ciências. Ciência \& Educação. Bauru. 2011. p. 835-854.

7. XAVIER, E.G.; LOPES, D.C.N.; PETERS, M.D.P. Organismos geneticamente modificados. Archivos de zootecnia. 2009. p. 15-33.

8. PAIVA, A. L. B.; MARTINS, C. M. C. Concepções prévias de alunos do terceiro ano do Ensino Médio a respeito de temas na área de Genética. Ensaio. p. 3454.2006 . 
9. AGUIAR, O.; MORTIMER, E. Tomada de Consciência de Conflitos: Análise da Atividade Discursiva em uma Aula de Ciências. Investigações em Ensino de Ciências. 2005. p. 179-207.

10. SOUZA, C. M.; et al. Comunicação da Ciência, Transgenia e Estudos CTS: a contribuição da informação para o debate público. In: $2^{\circ}$ Seminário Lecotec de Comunicação e Ciências. P. 84. São Paulo: Bauru. 2009.

11. MELO, J. R. CARMO, E. M. Investigações sobre o ensino de genética e biologia molecular no ensino médio brasileiro: Reflexões sobre as publicações científicas. Ciência \& Educação. 2009. p. 593-611.

12. SOUZA, M. M. Jogo de Regras: uma proposta lúdica para a retenção de conteúdos e procedimentos algébricos. (Dissertação de Mestrado em Educação). Universidade Católica de Brasília, Brasília, 2002.

13. ALVES, M; ALDA, J.; GEWANDSZNAJDER, F. O Método nas Ciências Naturais e Sociais: Pesquisa Quantitativa e Qualitativa. Pioneira. São Paulo. 1998.

14. COUTINHO, C. P. Quantitativo versus qualitativo: questões paradigmáticas na pesquisa em avaliação. In: XVIII Colóquio da Admee/Europa. Lisboa, Portugal. 2004. p. 443.

15. FARIAS, S. C. G; et al. Percepção dos Alunos da Universidade do Rio de Janeiro sobre a Produção e o Consumo de Transgênicos no Brasil. Revista Eletrônica do Prodema, 2014. P. 84-94.

16. SOUZA, A. F.; FARIAS, G. B. Percepção do conhecimento dos alunos do ensino médio sobre transgênicos: Concepções que influenciam na tomada de decisões. Experiências em Ensino de Ciências. pp. 2132. 2011.

17. OLIVEIRA, M. M. Sequência didática interativa no processo de formação de professores. Editora Vozes. Petrópolis. 2013.

18. GOMES, R. A; et al. Vivência de uma proposta educativa no ensino de biologia utilizando a sequência didática interativa a partir da temática da biotecnologia. In: XIII Jornada de ensino, pesquisa e extensão. Recife. (2013).

19. PAIVA, L. R.S.; et al. Jogo banco genômico: trabalhando com genes e organismos transgênicos, uma prática para o ensino de genética. Genética na Escola.p. 29-36.2008.

20. MOREIRA, P. G.; et al. Atividade Experimental na Escola - Um desafio no ensino básico ao licenciando. In: XX Simpósio Nacional de Ensino de Física, São Paulo, SP. 2013 